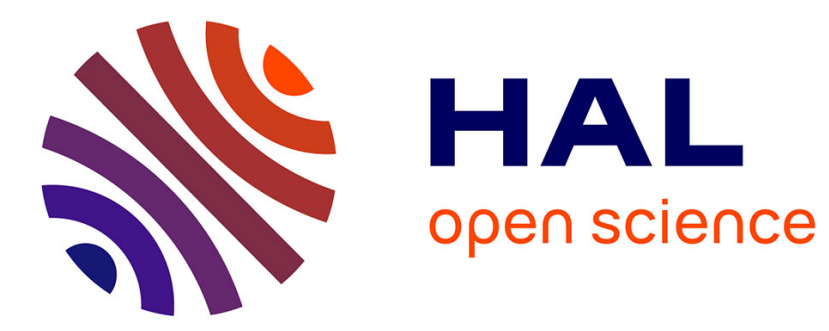

\title{
Gel to glass transformation in base catalysed silica
}

K. Dahmouche, C. Bovier, A. Boukenter, J. Dumas, E. Duval, C. Mai, J. Serughetti

\section{To cite this version:}

K. Dahmouche, C. Bovier, A. Boukenter, J. Dumas, E. Duval, et al.. Gel to glass transformation in base catalysed silica. Journal de Physique IV Proceedings, 1992, 02 (C2), pp.C2-127-C2-130. 10.1051/jp4:1992214. jpa-00251285

\section{HAL Id: jpa-00251285 https://hal.science/jpa-00251285}

Submitted on 1 Jan 1992

HAL is a multi-disciplinary open access archive for the deposit and dissemination of scientific research documents, whether they are published or not. The documents may come from teaching and research institutions in France or abroad, or from public or private research centers.
L'archive ouverte pluridisciplinaire HAL, est destinée au dépôt et à la diffusion de documents scientifiques de niveau recherche, publiés ou non, émanant des établissements d'enseignement et de recherche français ou étrangers, des laboratoires publics ou privés. 


\title{
Gel to glass transformation in base catalysed silica
}

\author{
K. DAHMOUCHE, C. BOVIER, A. BOUKENTER*, J. DUMAS, E. DUVAL*, C. MAI** \\ and J. SERUGHETTI
}

Département de Physique des Matériaux, UA 172 CNRS, Université Claude Bernard, Lyon I, 43 bd du 11 novembre 1918, 69622 Villeurbanne, France

"Physicochimie des Matériaux Luminescents, UA 442 CNRS, Université Claude Bernard, Lyon I, 43 bd du 11 novembre 1918, 69622 Villeurbanne, France

${ }^{* *}$ GEMPPM, UA 341 CNRS, INSA de Lyon, 20 avenue Albert Einstein, 69622 Villeurbanne, France

\begin{abstract}
The effects of heat-treatments on silica xerogels prepared from base catalyzed hydrolysis and condensation of TMOS are studied by lowfrequency Raman scattering, scanning electron microscopy, small angle $x$-ray scattering and BET measurements.

Raman scattering in the range $3-700 \mathrm{~cm}-1$ reveals a low-frequency band that arises from the discrete particulate character of base-catalysed gels at very small scale. A continuous evolution of the structure inside particles is observed during the thermal treatment and the Raman spectra is similar to the fused silica one after treatment at $1050^{\circ} \mathrm{C}$.

Electron microscopy observations of the nanostructure of the xerogels correlate with the particle Raman band maximum.

Complementary SAXS and BET measurements allows us to propose a model for the gel-to-glass transformation.
\end{abstract}

\section{INTRODUCTION}

Recent low frequency Raman scattering measurements of base-catalyzed silica aerogels showed the presence of a maximum at very low frequencies (1). This maximum arises from scattering from surfaces modes of structural units or spherical particles.For silica xerogels prepared in acid conditions and dried in atmosphere, no low frequency maximum was observed as in the base catalyzed aerogels (2).

on the other hand, Raman scattering from heat-treated base catalyzed silica aerogels showed three stages in the transformation to glass (3):1) modification of the particle surface 2)coalescence of the particles and 3 ) change of the internal structure and glass relaxation.

From these results, it appears interesting to follow the transformation of a base catalyzed xerogel with temperature by Raman scattering,but also by SAXS, scanning electron microscopy and BET measurements in order to understand the densification process.

\section{EXPERIMENTAL}

A) Technique

Gels were prepared by the hydrolysis and condensation of a solution of TMOS, methanol and water, in the presence of NH4OH and 
dimethylformamide (4). After drying at $160^{\circ} \mathrm{C}$ during $24 \mathrm{~h}$, the xerogel obtained had a specific surface of about $617 \mathrm{~m}^{2} / \mathrm{g}$, a pore volume of $1.46 \mathrm{~cm} 3 / \mathrm{g}$ and a mesopore radius of about $43 \mathrm{~A}$, as determined by $\mathrm{BET}$ measurements. The apparent density was about $0.56 \mathrm{~g} / \mathrm{cm} 3$.

The Raman measurements were obtained with a DILOR monochromator using the $5145 \mathrm{~A}$ line of an argon ion laser as an excitation source and a cooled photomultiplier. The range investigated varied from 3 to 700 $\mathrm{cm}^{-1}$. Fracture surfaces of Au20\%pt coated gels were observed with an HITACHI type S-800 scanning electron microscope.

The SAXS measurements were performed on a RIGAKU high power rotating anode generator(12 KW) with a position sensitive detector.A multichanel analyser connected to a microcomputer allows fast measurements. The $X$-rays beam of wavelength $1.54 \mathrm{~A}$ (Cuk $\alpha 1$ ) is focused on the detector plane by a curved monochromator. The $\mathrm{x}$-ray beam is held under vacuum in order to reduce air scattering.point-like slit conditions with an irradied cross section of about $1 \mathrm{~mm} 2$ are used. BET measurements were realized by the adsorption-desorption of nitrogen by the sample at very low temperature $\left(-196^{\circ} \mathrm{C}\right)$.

B) Experimental results and discussion

Figure $I$ shows the small angle $\mathrm{X}$-ray scattered intensity in function of the scattering vector $Q$ for xerogels annealed in air between $160^{\circ} \mathrm{C}$ and $1050^{\circ} \mathrm{C}$. On the one hand, the presence of a maximum located at 0,019 A-1 for the sample dried at $160^{\circ} \mathrm{C}$ (a) is observed.This peak is attributed to a correlation distance (about 332 A) between particles or clusters in the material. On the other hand, the SEM picture of this sample (figure 2) shows a microstructure consisting of spherical clusters with a mean diameter of about $300 \mathrm{~A}$ constituted of particles with a diameter of about 60 A. This allows to confirm that the maximum observed in figure 1 corresponds to the average distance between these clusters.

Secondly, Figure 1 shows also a shift of the maximum toward higher values of $Q$ with the increase of the temperature of heat-treatment. At $700^{\circ} \mathrm{C}$ (b) the correlation distance is about $314 \mathrm{~A}$, at $980^{\circ} \mathrm{C}$ (c) about $300 \mathrm{~A}$ and at $1030^{\circ} \mathrm{C}$ (d) about $290 \mathrm{~A}$.This shift reveals a collapse of the texture which is reorganized in the xerogel and that diminish the distance between the clusters.This phenomenon is confirmed by the increase of the width of the peak and by the decrease of the pore volume between $160^{\circ} \mathrm{C}(1.46 \mathrm{~cm} 3 / \mathrm{g})$ and $1030^{\circ} \mathrm{C}(0.3 \mathrm{~cm} / \mathrm{g})$. At $1050^{\circ} \mathrm{C}(e)$ the spectrum shows no scattering, attesting the transformation of the xerogel to glass.

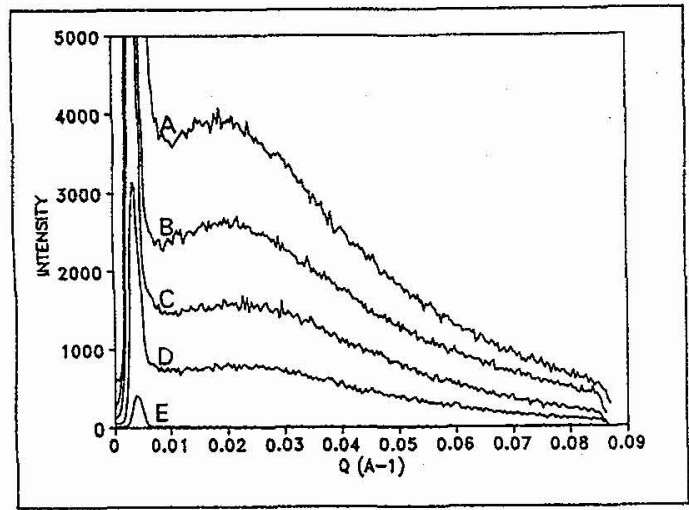

Figure 1. Saxs intensity (counts) in funcion of the scattering vector $Q$ from base-catalyzed xerogels:

(a) dried at $160^{\circ} \mathrm{C}$ (b) annealed for $30 \mathrm{mn}$ at $700^{\circ} \mathrm{C}$

(c) annealed for $30 \mathrm{mn}$ at $980^{\circ} \mathrm{C}$ (d) annealed for 30 $\mathrm{mn}$ at $1030^{\circ} \mathrm{C}(\mathrm{e})$ annealed for $30 \mathrm{mn}$ at $1050^{\circ} \mathrm{C}$.

The time of the saxs experiment is $1000 \mathrm{~s}$.



Figure 2: Scanning electron microscopy image of the xerogel aried at $160^{\circ} \mathrm{C}$. 
Now we can have informations about the structure of the material at shorter distance.

Figure 3 shows the reduced Raman spectra $I(\omega) /(n(\omega)+1)$ (where I $(\omega)$ is the Raman intensity, $\omega$ the frequency and $n(\omega)$ the Bose factor) up to $200 \mathrm{~cm}^{-1}$ for xerogels annealed in air between $160^{\circ} \mathrm{C}$ and $1050^{\circ} \mathrm{C}$. At first, we can see the presence of a very low frequency band located at $17 \mathrm{~cm}^{-1}$ for the sample dried at $160^{\circ} \mathrm{C}$ (a). This kind of peak has already been observed with base catalysed aerogels (1) and can be attributed to surface-vibrational modes of particles which are agregated to form the gel. The frequency $\omega_{0}$ of the maximum is a function (5) of the sound velocity $v$ in the particle and of the diameter $2 a: \omega 0=0.8(\mathrm{v} / 2 \mathrm{ac})$. Choosing a velocity $\mathrm{v}=4000 \mathrm{~m} / \mathrm{s}$, value slightly smaller than in silica,it is found $2 \mathrm{a}=60 \mathrm{~A}$, value which correlate with SEM observations (figure 2). The spectrum of this sample shows a line about $32 \mathrm{~cm}^{-1}$ probably due to the presence of DMF and organic compounds in the xerogel.

The spectrum of the sample annealed at $700^{\circ} \mathrm{C}$ for $30 \mathrm{mn}$ (b) shows no modification of the position of the low frequency band but reveals a narrowing of it.The spectrum of the sample annealed at $980^{\circ} \mathrm{C}$ (c) shows again a narrowing and a small shift of the band to $14 \mathrm{~cm}^{-1}$. After the annealing at this temperature, the calculated diameter of the particle is 76 A.This evolution of the very low frequency Raman scattering shows the growth of the largest particles at the expense of smaller ones due to the diminishing surface energy (6). At last, the spectrum of the sample annealed at $1050^{\circ} \mathrm{C}$ (d) is similar to the fused silica one (e) , attesting the transformation of the xerogel to glass at this temperature.

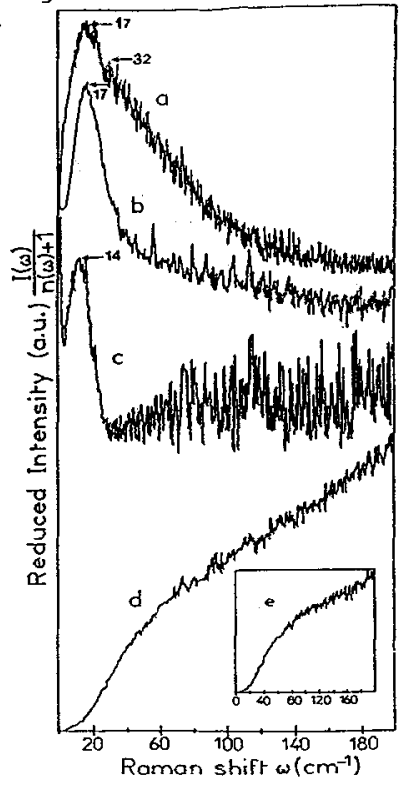

Now it is interesting to consider Raman scattering at higher frequencies, due to the vibrational modes inside the particles.In figure 4 the direct spectra $I(\omega)$ up to $700 \mathrm{~cm}^{-1}$ for the different previous heat-treatment are presented.We can see that the broad band (characteristic of the disorder at short distance) is located at $400 \mathrm{~cm}^{-1}$ for (a) and about $440 \mathrm{~cm}^{-1}$ for (b). It reveals that there is a modification of the internal structure in the particles between $160^{\circ} \mathrm{C}$ (apparent density $\left.=0.56 \mathrm{~g} / \mathrm{cm}^{3}\right)$ and $700^{\circ} \mathrm{c}$ (apparent density $=1 \mathrm{~g} / \mathrm{cm} 3$ ) which changes the disorder at short distance. On the other hand, the apparition of the line at $608 \mathrm{~cm}^{-1}$ (which corresponds to a 3-fold planar ring formed from three tetraedra(8)) for the sample heattreated at $700^{\circ} \mathrm{C}$ reflects the

Figure 3. Low-frequency Raman reduced intensity from base-catalyzed xerogels: (a) dried at $160^{\circ} \mathrm{C}$ (b) annealed for $30 \mathrm{mn}$ at $700^{\circ} \mathrm{C}$ (c) annealed for $30 \mathrm{mn}$ at $980^{\circ} \mathrm{C}$ (d) annealed for $30 \mathrm{mn}$ at $1050^{\circ} \mathrm{C}$. The spectrum of fused silica (e) is also represented:

particles. The surface which was rough becomes smooth (7). The line observed at $640 \mathrm{~cm}^{-1}$ for (a) is probably due to the presence of DMF and organic compounds in the dried gel at $160^{\circ} \mathrm{C}$. The comparison of these two spectra also shows that the line at $478 \mathrm{~cm}^{-1}$ observed in (a) shifts to about $490 \mathrm{~cm}^{-1}$ in (b). These lines at 478 and about $490 \mathrm{~cm}-1$ can be assigned to the 4-fold planar ring, respectively at the surface and 
inside the particles (9). This shift reflects again the modification of the surface of the silica particles from rough to smooth. The comparison between (b), (c) and (d) reveals that the line due to the 4-fold planar ring (located about $490 \mathrm{~cm}^{-1}$ ) increases compared to the line at 608 cm-1 due to the 3-fold planar ring. It shows the progressive evolution of the structure of the xerogel to the glass with the increasing of temperature, also reflected by the increasing of the intensity of the broad band compared to the line about $490 \mathrm{~cm}^{-1}$. At $1050^{\circ} \mathrm{C}$ (apparent density=2.19 $\mathrm{g} / \mathrm{cm} 3$ ), the spectrum (d) is similar to the fused silica one (e).

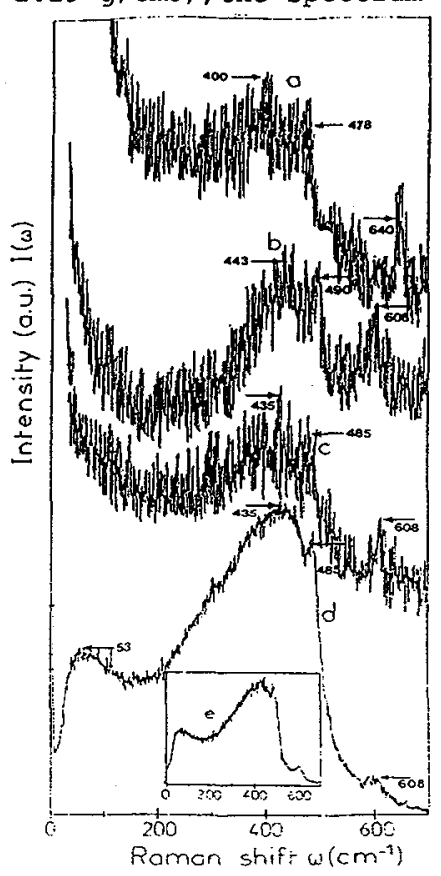

REEERENCES :

\section{CONCLUSION}

Our study allows the process of densification of base-catalyzed xerogels to be described.Two principal phenomenons can be distinguished. The first is revealed by SAXS, BET and SEM and shows that the texture of the material consisting of clusters with a diameter of about $300 \mathrm{~A}$ (constituted by beads of diametex about 60 A) collapse with the increase of temperature. The second is showed by Raman scattering and reveals a modification of the structure at shorter distance with three stages:smoothing of the particles (beads), small growth of their size, modification of the structure inside the beads.

Figure 4. Raman intensity from base-catalyzed xerogels:

(a-e) same samples as in figure 3

(1):A.Boukenter, B. Champagnon, E.Duval, JL.Rousset, J.Dumas and J.Serughetti.J PHYS C:solid state phys:21 (1988) I 1097-1102

(2) :A.Boukenter, B. Champagnon, E.Duval, J.Dumas, JF.Quinson and J.Serughetti, Phys Rev Letter 57 (1986) 2391.

(3) : JL.Rousset, E.Duval, A. Boukenter, B. Champagnon, A. Monteil, J.Dumas, and

J.Serughetti,Journal of non-crystalline solids 107 (1988) 27-34

(4) : T.Adachi, S.Sakka, Journal of materials science 22 (1987) 4407-4410

(5): E. Duval, A.Boukenter and B.Champagnon, Phys Rev Letter 56 (1986) 2052

(6): CAM.Mulder, JG.Van Lierop and G.Frens, Journal of non-crystalline solids

82 (1986) 92-96

(7) : FL.Galeener, sol St Commun 44 (1982) 1037

(8) : R.Vacher, T.Woignier, J.Pelous and E.Courtens, Phys Rev B 37 (1988) 6500

(9) : GE.Walfaren, MS Hokmamadi and NC.Holmes, J Chem Phys 85 (1986) 771 